\title{
PENURUNAN RASA HAUS DENGAN PERMEN KARET PADA PASIEN GGK YANG MENJALANI HEMODIALISA
}

\author{
${ }^{1}$ Zakiyah Hasibuan, ${ }^{2}$ Yulis Hati \\ ${ }^{1}$ Mahasiswa Program Studi Ilmu keperawatan Universitas Haji Provinsi Sumatera Utara \\ ${ }^{2}$ Dosen Program Studi Ilmu keperawatan Universitas Haji Provinsi Sumatera Utara \\ hasibuanzakiyah05@gmail.com
}

\begin{abstract}
Abstrak
Terapi hemodialisa merupakan salah satu cara penderita GGK untuk bisa bertahan hidup dan harus mempertahankan pembatasan asupan cairan. Pembatasan cairan menimbulkan keluhan rasa haus. Strategi mengurangi rasa haus adalah pemberian permen karet yang kemudian terjadinya stimulasi kelenjar saliva yang menyebabkan produksi saliva meningkat. Tujuan penelitian ini untuk mengetahui penurunan rasa haus dengan permen karet pada pasien GGK yang menjalani hemodialisa. Jenis penelitian menggunakan Quasy ekspriment dengan desain one group pretest postest. Populasi penelitian adalah seluruh pasien GGK yang menjalani hemodialisa sebanyak 43 orang. Teknik pengambilan sampel menggunakan purposive sampling dengan jumlah sampel 20 orang. Instrumen penelitian menggunakan lembar kuisioner. Analisa data dilakukan dengan analisa univariat dan bivariat menggunakan uji wilcoxon test. Hasil penelitian menunjukkan bahwa sebelum intervensi mayoritas rasa haus sedang sebanyak 10 orang, dan sesudah intervensi mayoritas rasa haus ringan sebanyak 13 orang. Hasil analisa data menunjukkan nilai $p_{\text {value }}$ sebesar $0,001(<0,05)$ dengan $(\mathrm{SD}=6.343)$. Kesimpulan penelitian ini terdapat penurunan rasa haus dengan permen karet pada pasien GGK yang menjalani hemodialisa. Diharapkan penelitian ini menjadi sumber informasi bagi Pasien GGK yang menjalani hemodialisa dan pihak rumah sakit tentang manfaat pemberian permen karet dan sebagai salah satu terapi untuk menurunkan rasa haus pada pasien GGK yang menjalani hemodialisa.
\end{abstract}

Kata kunci $\quad$ : Hemodialisa, Rasa Haus, Permen karet

\begin{abstract}
Hemodialysis therapy is one way for patients with chronic kidney failure to survive and must maintain fluid intake restrictions. Fluid restriction causes complaints of thirst. The strategy to reduce thirst is to give chewing gum, which then stimulates the salivary glands which causes salivary production to increase. The aim of this study was to determine the reduction of thirst with chewing gum in chronic renal failure patients undergoing hemodialysis. This type of research uses Quasy experiment with one group pretest postest design. The study population was all patients with chronic renal failure who underwent hemodialysis as many as 43 people. The sampling technique used purposive sampling with a sample size of 20 people. The research instrument used a questionnaire sheet. Data analysis was performed by univariate and bivariate analysis using the Wilcoxon test. The results showed that before the intervention the majority of moderate thirst was 10 people, and after the intervention the majority of mild thirst was 13 people. The results of data analysis showed a p-value of $0.001(<0.05)$ with $(S D=6.343)$. The conclusion of this study is that there is a reduction in thirst with chewing gum in patients with chronic renal failure undergoing hemodialysis. It is hoped that this study will be a source of information for chronic renal failure patients undergoing hemodialysis and the hospital about the benefits of giving chewing gum and as a therapy to reduce thirst in chronic renal failure patients undergoing hemodialysis.s
\end{abstract}

Keywords $\quad$ : Hemodialysis, Thirst, Gum 


\section{Pendahuluan}

GGK (GGK) merupakan fungsi ginjal yang tidak stabil secara cepat dan terjadinya ketidak seimbangan metabolik pencernaan, cairan dan elektrolit tubuh yang mengakibatkan uremia atau azotemia (Brunner \& Suddarth, 2000 dalam Andra, 2013). Kondisi ini disebabkan oleh glomerulonefritis kronik, pielonefritis, hipertensi tak terkontrol, lesi herediter, kelainan vaskular, obstruksi saluran perkemihan, diabetes, dan infeksi (Baughman \& Hackley, 2012). Komplikasi yang sering dihadapi pasien penyakit GGK adalah anemia, edema paru, ketidakseimbangan elektrolit, penyakit kardiovaskular, dan hipertensi (Bilotta, 2013). Apabila seseorang terkena GGK maka penyakit tersebut tidak bisa disembuhkan dan memerlukan pengobatan berupa, transplantasi ginjal, dialisis peritoneal, hemodialisa dan rawat jalan dalam jangka waktu yang lama untuk mempertahankan hidup (Black, 2014).

Estimasi Badan Kesehatan Dunia (WHO), secara global lebih dari 500 juta orang mengalami penyakit ginjal kronik. Sekitar 1,5 juta bergantung pada cuci darah (hemodialisa) (Ratnawati, 2014). Angka kejadian GGK berdasarkan data dari Riskesdas pada tahun 2013, prevalensi GGK 0,2\% dari penduduk Indonesia. Hanya $60 \%$ dari pasien GGK tersebut yang menjalani terapi hemodialisa (Riskedas, 2013).

Hemodialisa merupakan suatu proses terapi pengganti terhadap ginjal dengan menggunakan selaput membran semipermeabel yang berfungsi seperti nefron yaitu penyusun utama ginjal yang berperan penting dalam proses penyaringan darah sehingga dapat mengeluarkan produk sisa metabolisme dan mengkoreksi gangguan keseimbangan cairan dan elektrolit pada pasien gagal ginjal (Ignativicus, 2010). Tujuan terapi Hemodialisa adalah mencegah kematian walau bersifat tidak menyembuhkan atau memulihkan penyakit dan tidak mampu mengimbangi hilangnya aktivitas metabolik yang dilakukan ginjal. Hemodialisa pada umumnya sebanyak 2 kali seminggu dengan waktu selama 5 jam atau sebanyak 3 kali seminggu dengan waktu 4 jam selama melakukan hemodialisa (Suwitra, 2006 dalam Imam, 2010).

Dilaporkan dari The United States Renal Data System (USRDS) tahun 2013 menunjukkan angka prevalensi pasien GGK yang menjalani hemodialisa pada tahun 2013 di Amerika Serikat sebesar 1.924 per 1 juta penduduk, di Singapura sebesar 1.661 per 1 juta penduduk, dan di Jepang sebesar 2.309 per 1 juta penduduk per tahun (menurut USRDS 2013 dalam Kusuma, 2013).RSUP Haji Adam Malik dijumpai 154 orang kasus gagal ginjal, di RSUD Dr. Pringadi dijumpai sebanyak 109 orang kasus gagal ginjal, di RS Swasta (RS Rasyida) sebanyak 78 orang kasus gagal ginjal yang secara rutin menjalani pengobatan hemodialisa (Aroem, 2011).

Terapi hemodialisa merupakan salah satu cara bagi penderita GGK untuk bisa bertahan hidup. Dengan tujuan untuk membuang produk sisa metabolisme dari peredaran darah manusia melalui membran semipermeabel atau disebut dialiser. Penderita GGK menjadikan hemodialisa sebagai rutinitas dan pasien yang menjalani hemodialisa harus mempertahankan pembatasan asupan cairan sehingga tercapai keseimbangan cairan tubuh agar tidak terjadi kelebihan cairan (Harsimanto, Rifai dan Tuti, 2008; Price \& Wilson, 2013).

Pasien GGK melangami xerostomia atau kehausan padahal tubuhnya terjadi kelebihan cairan yang dapat menyebabkan penambahan berat badan, edema peningkatan tekanan darah, sesak nafas, dan gangguan jantung yang menurunkan kualitas hidup pasien, maka dari itu pembatasan cairan harus dilakukan pada pasien hemodialisa agar terjadinya keseimbangan cairan (Guyton \& Hall, 2016). Rasa haus adalah respon fisiologis dari dalam tubuh manusia berupa keinginan untuk minum guna memenuhi kebutuhan cairan dalam tubuh. Rasa haus atau mulut kering, yang menyebabkan 
ketidaknyamanan dan penderitaan pada pasien hemodialisa sehingga dapat mempengaruhi kualitas hidup (Fan \& Zhang, 2013). Hemodialisa di indonesia tidak dilakukan setiap hari sehingga Pasien dengan penyakit ginjal kronik yang menjalani hemodialisa mengalami masalah penumpukan cairan diantara dua waktu dialisis sehingga perlu dilakukan pembatasan cairan.

Akibat pembatasan cairan maka menimbulkan rasa haus, jika rasa haus tersebut tidak diatasi akan menimbulkan peningkatan intake cairan yang mengakibatkan masalah kelebihan cairan sehingga menimbulkan berbagai komplikasi (Anis, 2015). Hal ini merupakan masalah yang penting yaitu dengan melakukan menajemen rasa haus yang salah satunya dengan cara pemberian permen karet. Pemberian permen karet tanpa efek samping akan menyebabkan terjadinya stimulasi pada kelenjar saliva, implus akan berjalan ke nukleus didalam medulla ditambah dengan pergerakan otot-otot mulut akibat proses mengunyah akan merangsang peningkatan produksi saliva (Cahaya, 2017). Terapi ini didukung oleh studi yang dilakukan di belanda, dimana peneliti membandingkan efektifitas permen karet (Freedent White TM) aroma mentol yang yang bebas gula dengan penggunaan saliva buatan (Xialine TM) untuk mengatasi xerostomia pada pasien hemodialisis.

Dalam penelitian yang dilakukan oleh (Andreas, 2019) pada jurnal Pengaruh Mengunyah Permen Karet Terhadap Penurunan Rasa Haus Pada Pasien Hemodialisa didapatkan hasil dengan Kegiatan mengunyah permen karet rendah gula dua butir \pm 10 menit dengan $3 \times /$ hari selama 2 minggu akan menimbulkan rangsangan mekanis dan kimiawi yang dapat menggerakkan refleks saliva dengan menstimulasi reseptor yang dipantau oleh nervus trigeminal (V) dan nervus fasial (VII) sebagai pengecap. Stimulasi terhadap saraf simpatis akan mempercepat sekresi kelenjar saliva dalam jumlah banyak yang dapat menurunkan sensasi rasa haus (Said \& Mohammed, 2013). Hemodialisa ratarata dilakukan 2-3 kali seminggu dengan durasi 4-5 jam, bergantung pada sistem hemodialisa yang digunakan dan keadaan pasien (Diyah, 2015).

Data yang didapat dari rekam medik di RSU Haji Provinsi Sumatera Utara pada tanggal 27 Desember 2019 didapatkan 10 pasien hemodialisa. Dari hasil wawancara yang dilakukan oleh peneliti kepada pasien yang sedang menjalani hemodialisa 7 diantaranya mengatakan merasakan haus dan 3 pasien mengatakan merasakan biasa saja. Baik perawat maupun pasien hemodialisa di RSU Haji Provinsi Sumatera Utara mengatakan bahwa belum pernah dilaksanakannya terapi yang tujuannya untuk mengurangi rasa haus pasien yang menjalani hemodialisa.

Berdasarkan uraian dari latar belakang diatas oleh sebab itu peneliti tertarik untuk melakukan penelitian tentang "Penurunan Rasa Haus dengan Permen Karet Pada Pasien GGK Yang Menjalani Hemodialisa di RSU Haji Provinsi Sumatera Utara”.

\section{Metode Penelitian}

Metode penelitian ini penelitian kuantitatif, desain penelitian quasi eksperimen dengan One group pretest and post test, suatu penelitian yang dilakukan dengan satu kelompok yang diberi perlakuan tertentu, kemudian diobservasi sebelum dan sesudah perlakuaan, dimana observasi dilakukan sebanyak dua kali yaitu sebelum (pretest) dan sesudah (post test).

Penelitian ini mengungkap hubungan sebab akibat dengan cara melibat satu kelompok yang akan diberikan perlakuan. Penelitian ini dilakukan di Ruang Hemodialisa RS. Umum Haji Provinsi Sumatera Utara. Populasi pada penelitian ini adalah semua penderita GGK yang sedang menjalani hemodialisis berjumlah 43 orang. Teknik 
sampling yang digunakan adalah Purposive sampling dan dengan menggunakan rumus slovin didapatkan sampel berjumlah 20 responden sesuai dengan kriteria inklusi dan eksklusi. Alat pengumpulan data pada penelitian ini berupa Permen karet rendah gula, lembar observasi dan kuesioner.

Sedangkan untuk mengetahui tingkat rasa haus responden menggunakan kuisioner Thirst Distres Scale (TDS).Variabel Independent pada penelitian ini yaitu pemberian permen karet dan variabel Dependent yaitu rasa haus. Teknik analisa data yang dilakukan analisa univariat dan bivariate.

\section{Hasil}

1. Distribusi frekuensi berdasarkan usia $(\mathrm{n}=\mathbf{2 0})$

\begin{tabular}{lrr}
\hline \multicolumn{1}{c}{ Variabel } & n & \% \\
\hline Usia & & \\
1. Dewasa & 7 & 35.0 \\
2. Lansia & 13 & 65.0 \\
\hline \multicolumn{1}{c}{ Total } & 20 & 100,0 \\
\hline
\end{tabular}

Berdasarkan tabel diatas dapat dilihat dari 20 orang pasien GGK yang menjalani hemodialisa di RSU Haji Provinsi Sumatera Utara mayoritas kategori lansia dengan umur (46-65) tahun $(65.0 \%)$

\section{Distribusi frekuensi berdasarkan jenis kelamin $(n=20)$}

\begin{tabular}{lrr}
\hline Jenis Kelamin & & \\
1. Laki-laki & 10 & 50.0 \\
2. Perempuan & 10 & 50.0 \\
\hline \multicolumn{1}{c}{ Total } & 20 & 100,0 \\
\hline
\end{tabular}

Berdasarkan tabel diatas dapat dilihat dari penelitian ini jenis kelamin berimbang sama, laki-laki sebanyak 10 orang $(50.0 \%)$ dan perempuan sebanyak 10 orang $(50,0 \%)$.

3. Distribusi frekuensi berdasarkan lama hemodialisis $(\mathbf{n}=\mathbf{2 0})$

\begin{tabular}{crc}
\hline Lama Hemodialisa & & \\
$1 .<1$ tahun & 5 & 25.0 \\
$2 . \quad 1-5$ tahun & 15 & 75.0 \\
\hline Total & 20 \\
\hline
\end{tabular}

Berdasarkan tabel diatas dapat dilihat dari lama hemodialisa dengan lama hemodialisa 1-5 tahun berjumlah 5 responden (75.0\%). 
a. Distribusi Frekuensi Rasa Haus Pasien GGK Yang Menjalani Hemodialisa Sebelum Diberikan Permen Karet Di RSU Haji Provinsi Sumatera Utara Tahun 2020

\begin{tabular}{llcc}
\hline No & Variabel & F & $\%$ \\
\hline 1 & Haus ringan & 1 & 5.0 \\
2 & Haus sedang & 10 & 50.0 \\
3 & Haus berat & 9 & 45.0 \\
\hline & Jumlah & $\mathbf{2 0}$ & $\mathbf{1 0 0 . 0}$ \\
\hline
\end{tabular}

Berdasarkan tabel dapat dilihat bahwa sebelum diberikan permen karet mayoritas responden mengalami haus sedang sebanyak 10 orang $(50.0 \%)$.

b. Distribusi Frekuensi Rasa Haus Pasien GGK Yang Menjalani Hemodialisa Sesudah Diberikan Permen Karet Di RSU Haji Provinsi Sumatera Utara Tahun 2020

\begin{tabular}{llcc}
\hline No & Variabel & F & \% \\
\hline 1 & Haus ringan & 13 & 65.0 \\
2 & Haus sedang & 4 & 20.0 \\
3 & Haus berat & 3 & 15.0 \\
\hline & Jumlah & $\mathbf{2 0}$ & $\mathbf{1 0 0 . 0}$ \\
\hline
\end{tabular}

Berdasarkan tabel 4.3 dapat dilihat bahwa sesudah diberikan permen karet mayoritas responden mengalami haus ringan sebanyak 13 orang $(65.0 \%)$.

c. Hasil Uji Wilcoxon Pada Responden Yang Diberikan Permen Karet Terhadap Rasa Haus Pasien GGK Yang Menjalani Hemodialisa Di RSU Haji Provinsi Sumatera Utara Tahu 2020

\begin{tabular}{ccccccc}
\hline \multirow{2}{*}{$\begin{array}{r}\text { Rasa } \\
\text { haus }\end{array}$} & \multicolumn{6}{c}{ Perubahan rasa haus } \\
\cline { 2 - 7 } & $\boldsymbol{F}$ & $\boldsymbol{\%}$ & $\boldsymbol{F}$ & $\boldsymbol{\%}$ & $\boldsymbol{f}$ & Berat \\
\hline Pretest & 1 & 5.0 & 10 & 50.0 & 9 & \% \\
Postest & 13 & 65.0 & 4 & 20.0 & 3 & 45.0 \\
\hline
\end{tabular}




\begin{tabular}{llcc}
\hline Mean & SD & $\boldsymbol{Z}$ & $\begin{array}{c}\mathbf{P} \\
\text { value }\end{array}$ \\
\hline 13.35 & 6.343 & -3.347 & 0.001 \\
\hline
\end{tabular}

Berdasarkan tabel 4.4 diatas dapat dilihat bahwa Setelah dilakukan uji signifikansi menggunakan uji Wilcoxon diperoleh Pvalue $=0.001(<0.05)$, dengan $(\mathrm{Z}=-3.347)$ yang artinya kurang dari 3.347 kali tidak haus responden yang diberikan permen karet dibandingkan responden yang tidak diberikan permen karet, maka dapat diambil kesimpulan bahwa terjadinya penurunan rasa haus dengan pemberian permen karet pada pasien GGK yang menjalani hemodialisa di RSU Haji Provinsi Sumatera Utara Tahun 2020.

\section{Pembahasan}

\section{Rasa Haus pada pasien GGK yang menjalani hemodialisa sebelum pemberian permen karet di RSU Haji Provinsi Sumatera Utara Tahun 2020}

Berdasarkan hasil penelitian diketahui bahwa, rasa haus pada pasien GGK yang menjalani hemodialisa di RSU Haji Provinsi Sumatera Utara Tahun 2020 mayoritas pasien gagal ginjal kronis yang menjalani hemodialisa merasakan haus sedang (14-21) sebanyak 10 orang. Pasien GGK merasakan haus karena asupan cairan pada pasien GGK di batasi sesuai dengan hasil pengukuran kebutuhan cairan klien. Pembatasan cairan bertujuan untuk mengurangi kelebihan cairan jika tidak dikurangi dapat menjadi edema, hipertensi, dan hipertropi ventrikel kiri (Istanti, 2013 dalam Sari, 2016).

Munculnya rasa haus merupakan fenomena penting dimana terjadinya mekanisme dasar yang dialami tubuh manusia sebagai sinyal atau tanda kebutuhan akan cairan (air) dalam tubuh untuk mempertahankan kebutuhan cairan. Karena dalam tubuh manusia jumlah air harus seimbang pada setiap saat antara yang masuk dan yang keluar. Jika tidak seimbang (jumlah air yan keluar lebih banyak dibanding yang masuk), maka akan muncul rasa haus (Guyton, 2012).

Rasa haus merupakan proses pengaturan primer asupan cairan. Dimana Pusat rangsangan haus di hipotalamus otak dekat sel penghasil vasopresin untuk pengeluaran urin dan rasa haus (keinginan untuk minum) bekerja secara berkesinambungan. Sekresi vasoprin serta rasa haus dirangsang oleh kekurangan cairan dan dikendalikan oleh kelebihan cairan. Itu menjadi penyebab kejadian penurunan pengeluaran urin untuk menghemat cairan tubuh dapat menimbulkan rasa haus untuk mengganti kehilangan cairan tubuh (Sherwood, 2012).

Faktor lain yang memicu munculnya rasa haus menurut ( Arfany, dkk. 2014) dan (Ardiyanti, dkk. 2015) adalah prosedur hemodialisis pada Pasien GGK yang tidak dilakukan setiap hari akan memicu munculnya masalah penumpukan cairan diantara sesi dialisis. yang menyebabkan berat badan pasien bertambah, tekanan darah meningkat, sesak nafas, gangguan jantung, dan edema karena ginjal tidak mampu mengeluarkan cairan. Retensi natrium dan air terjadi akibat hilangnya fungsi ginjal, sehingga fungsi tubulus juga hilang yang mengakibatkan sekresi urine encer dan terjadi dehidrasi (O' challaghan, 2009, hlm. 95: Ardiyanti, 2015). Dehidrasi ini menyebabkan peningkatan osmolalitas, sehingga sel akan mengkerut dan muncul perasaan haus (Kowalak, 2011). 
Hasil penelitian yang yang dilakukan di RSU Haji Provinsi Sumatera Utara didapatkan usia responden terbanyak adalah kategori lansia (46-69 tahun) sebanyak 13 responden $(65.0 \%)$ dengan usia termuda adalah dewasa yaitu 26 tahun dan usia tertua adalah lansia yaitu 69 tahun.

Menurut kozier, Erb, Berman dan Snyder (2011) faktor keseimbangan cairan tubuh, elektrolit, dan asam-basa dipengaruhi oleh salah satunya adalah faktor usia. Kebutuhan cairan tubuh manusia manusia dipengaruhi oleh usia dimana kebutuhan cairan tubuh yang harus dipenuhi berbeda-beda karena dalam masa pertumbuhan bayi dan anak mengalami perpindahan cairan lebih besar dan laju metabolisme lebih tinggi dari pada orang dewasa yang mengakibatkan terjadinya peningkatan kehilangan cairan. Kehilangan cairan pada bayi dipengaruhi oleh belum matangnya organ ginjal. Kehilangan cairan pada usia lanjut dipengaruhi oleh proses penuaan dan cenderung terhadap penyakit yang meliputi: respon haus yang kurang dirasakan sering kali terjadi, kadar hormon antideuretik yang normal atau meningkat tetapi pada nefron terjadi penurunan kemampuan menyimpan air sebagai respon terhadap Antidiuretic Hormone (ADH), peningkatan kadar natriuretik atrial. Selain itu, adanya kecenderungan terhadap penyakit jantung, ginjal, dan regimen obat multipel, risiko terjadinya ketidakseimbangan cairan dan elektrolit lebih signifikan (Kozier, Erb, Berman dan Snyder, 2011).

Hal ini sesuai dengan penelitian Febriyantara (2016) yang mendapatkan hasil sebagian besar responden GGK berada pada rentang usia >50 tahun sebanyak 22 responden (37,3\%). Risiko GGK akan meningkat sejalan dengan bertambahnya usia dan pola hidup yang tidak sehat. Berdasarkan hasil penelitian N. W. Arfany (2014) yang menyatakan bahwa kasus penyakit ginjal kronis cenderung meningkat pada usia dewasa karena proses perjalanan penyakitnya yang bersifat kronis dan progresif. Semakin bertambahnya usia secara bersamaan fungsi renal dan traktus urinarius serta fungsi tubulus termasuk kemampuan reabsorbsi akan berkurang. Setelah usia 40 tahun laju filtrasi glomerulus akan mengalami penurunan secara progresif kurang dari $50 \%$ dari normalnya hingga usia 70 tahun. Kebutuhan asupan cairan pada lansia menurun seiring dengan proses menua yang disebabkan oleh terjadinya perubahan komposisi tubuh, yaitu menurunnya sel-sel lemak yang menyebabkan menurunnya kebutuhan cairan untuk menjalankan fungsi tubuh (Fatmah, 2010).

Rasa haus pada pasien GGK yang menjalani hemodialisa sesudah pemberian permen karet di RSU Haji Provinsi Sumatera Utara Tahun 2020

Berdasarkan hasil penelitian diketahui bahwa, rasa haus pada pasien GGK yang menjalani hemodialisa setelah pemberian permen karet di RSU Haji Provinsi Sumatera Utara tahun 2020 mayoritas pasien GGK yang menjalani hemodialisa merasakan haus ringan (6-13) sebanyak 13 orang.

Berdasarkan data yang diperoleh terdapat perubahan rasa haus setelah adanya pemberian permen karet, dimana responden yang semula pasien gagal ginjal kronis yang menjalani hemodialisa merasakan haus berat, namun setelah intervensi, pasien gagal ginjal kronis yang menjalani hemodialisa merasakan haus ringan, atau yang semula pasien gagal ginjal kronis yang menjalani hemodialisa merasakan haus sedang berubah menjadi haus ringan.

Pemberian permen karet pada pasien GGK yang menjalani hemodialisa sebanyak 3 butir permen karet dengan lama waktu mengunyah \pm 15 menit, selama waktu hemodialisa mayoritas pasien dapat menahan rasa haus selama 90 menit kemudian setelah mengunyah permen karet dengan lama hemodialisa 4-5 jam. Hasil penelitian ini sesuai dengan teori Said \& Mohammed (2013) bahwa menguyah permen karet akan menimbulkan rangsangan mekanis dan kimiawi yang dapat menggerakkan reflek saliva dengan menstimulasi reseptor yang dipantau oleh nervus trigeminal (V) dan nervus fasial 
(VII) sebagai pengecap. Stimulus saraf simpatis akan mempercepat sekresi pada semua kelenjar saliva dalam jumlah banyak yang dapat menurunkan sensasi rasa haus yang muncul. Mengunyah permen karet xylitol merupakan refleks saliva terstimulasi dengan melibatkan stimulus mekanik (gerak pengunyahan) dan kimiawi (pengecapan) (Furness, Brayan, Mcmillan \& Hv, 2013).

Xylitol merupakan zat penganti gula dengan tingkatan rasa yang manis yang sama dengan sukrosa tetapi $40 \%$ kandungan kalorinya lebih rendah, xylitol adalah salah satu jenis gula akohol atau keluarga polyol, termasuk pemanis jenis lainnya seperti sorbitol, mannitol, dan maltitol. Xylitol dapat ditemukan dengan jumlah kecil pada buah-buahan, sayuran dan diproduksi melalui proses metabolisme tubuh (Marya, 2011 dalam Alfrida, 2019)

Xylitol adalah komponen penyusun berbagai buah dan sayuran, meskipun jumlahnya kurang dari 1\%. Tubuh manusia juga menghasilkan 5-15 gram xylitol dari proses metabolisme karbohidrat (Rietveld et al., 2013). Xylitol adalah pemanis yang aman untuk gigi, xylitol dalam permen karet banyak digunakan sebagai pengganti sukrosa. Xylitol memiliki derajat kemanisan yang sama dengan sukrosa namun memiliki kandungan kalori yang lebih sedikit yaitu sekitar 40\% (Rodian, Satari, \& Rolleta, 2011). Xylitol berperan aktif dalam memperbaiki kavitas kecil yang disebabkan oleh karies karena menghambat akumulasi plak gigi. Xylitol tidak dapat dimetabolisme oleh bakteri oral termasuk Streptococcus mutans dan bila xylitol berkontak dengan Streptococcus mutans akan terbentuk xylitol 5 fosfat yang menyebabkan kerja substansi yang berperan dalam proses glikolisis seperti glukosa 6 fosfat, fruktosa 6 fosfat, bifosfat , 3 fosfogliserat, 2 fosfogliserat dan fosfoenolpiruvat terhambat (Rodian et al., 2011). Xylitol juga mendukung proses remineralisasi dan memperkuat email gigi karena menyebabkan aliran saliva bertambah sehingga dapat menormalkan $\mathrm{Ph}$ rongga mulut dan menetralisir semua asam yang telah terbentuk. Oleh karena itu xylitol bersifat non kariogenik yang dapat menekan pertumbuhan koloni Streptococcus mutans, menghambat akumulasi plak dan menekan keasaman saliva. Pemberian produk yang mengandung xylitol dapat menstimulasi produksi saliva, mengubah komposisi saliva, dan meningkatkan konsentrasi bikarbonat, fosfat, serta kalsium. Perubahan komposisi ini menstimulasi peningkatan kemampuan terbentuknya kristas hidroksiapatit. Peningkatan laju produksi saliva cenderung membersikan gula dan asam dari gigi (Rodian et al., 2011).

Penelitian ini sejalan dengan penelitian yang dilakukan oleh Arfany, Armiyanti, \& Kusuma (2014) efektifitas mengunyah permen karet rendah gula sebagai cara mengatasi rasa haus pada pasien GGK telah dibuktikan pada penelitian yang melibatkan 65 pasien yang melakukan terapi hemodialisa dan diberikan permen karet selama 2 minggu menunjukkan penurunan rasa haus pada pasien GGK dari skor 29,9 menjadi 28,1.

Menurut asumsi peneliti pemberian permen karet xylitol sangat bagus diberikan untuk pasien GGK yang menjalani hemodialisa untuk intervensi sebagai mengurangi rasa haus, sebagai tindakan pembatan cairan pasien hemodialisa, dan memberikan sensasi segar dimulut.

Penurunan Rasa Haus dengan permen karet pada pasien GGK yang menjalani hemodialisa di RSU Haji Provinsi Sumatera Utara tahun 2020

Berdasarkan hasil penelitian diketahui bahwa, rasa haus mean atau rata-rata pada pasien gagal ginjal kronis yang menjalani hemodialisa di RSU Haji Provinsi Sumatera Utara Tahun 2020 ada perubahan rasa haus sebelum dan setelah dilakukan intervensi pemberian permen karet kepada responden sebanyak 20 orang.

Hasil analisis dengan uji Wilcoxon test juga menunjukkan nilai sig. atau nilai Pvalue sebesar 0,001 <0,05, dengan rata-rata rasa haus sebelum intervensi adalah 20.75, standar deviasi 4.711 dengan nilai minimal 12 dan nilai maksimal 28. Sedangkan rasa 
haus sesudah dilakukan intervensi didapatkan nilai dan rata-rata 13.35 dengan standar deviasi 6.343 dengan nilai minimal 7 dan nilai maksimal 28. Dan didapatkan sebanyak 3 responden yang tetap mengalami haus berat baik sebelum intervensi maupun setelah intervensi. Hal tersebut disebabkan 2 responden mengatakan tidak suka dengan permen karet dan 1 responden yang mengalami kecemasan karena masih menjalani hemodialisa dalam beberapa bulan ini. jika pasien GGK yang menjalani hemodialisa tidak mendapatkan apapun. Walaupun dengan mengunyah permen karet mengakibatkan saliva bertambah hal tersebut tidak akan menjadi gangguan, karena saliva juga berfungsi untuk mempermudah proses menelan dan membasahi partikel-partikel makanan. hal ini menunjukkan bahwa sangat berpengaruh pemberian permen karet terhadap rasa haus pada pasien gagal ginjal kronis yang menjalani hemodialisa di RSU Haji Provinsi Sumatera Utara Tahun 2020.

Hal ini diperkuat oleh penelitian Mohammad Fajar Sodik, dkk (2018) yang menunjukkan bahwa pemberian permen karet dapat menahan rasa haus pada pasien yang menjalani hemodialisa. Hasil yang didapatkan pada pemberian permen karet dengan lama waktu menahan rasa haus pasien yang menjalani hemodialisa di RSUD. Dr. M. Haulussy Ambon menunjukkan nilai pvalue 0,000 dan lama waktu menahan rasa haus pada pre-test tanpa pemberian permen karet didapatkan hasil rata-rata 59,69 menit. Sedangkan lama waktu menahan rasa haus pada post-test responden dengan mengunyah permen karet didapatkan hasil rata-rata 105, 17 menit.

Hasil penelitian ini sejalan dengan penelitian yang dilakukan N. W. Afany (2014) tentang efektifitas mengunyah permen karet rendah gula pada pasien penyakit ginjal kronis yang menjalani hemodialisa di RSUD Tugurejo Semarang yang mendapatkan hasil pvalue 0,000 dengan tingkat rasa haus sebelum diberikan intervensi mengunyah permen karet rendah gula menunjukkan nilai rerata 5,08, setelah diberikan intervensi rerata tingkat rasa haus turun menjadi 4,08 sehingga terjadi penurunan tingkat rasa haus sebesar 20\%. Penelitian oleh Asmira Dewi, dkk (2018) juga menunjukkan terdapat perubahan yang signifikan terhadap mengunyah permen karet terhadap rasa haus pasien gagal ginjal kronis yang menjalani hemodialisa di RSUD Arifin Achmad rasa haus sebelum diberikan intervensi dan setelah diberikan intervensi.

Menurut asumsi peneliti, terdapat pengaruh pemberian permen karet terhadap rasa haus pasien GGK yang menjalani hemodialisa di RSU Haji Provinsi Sumatera Utara Tahun 2020.

\section{Kesimpulan}

Berdasarkan hasil penelitian tentang pengaruh pemberin permen karet terhadap rasa haus pada pasien GGK yang menjalani hemodialisa di RSU Haji Provinsi Sumatera Utara Tahun 2020, diperoleh kesimpulan sebagai berikut :

1. Mayoritas rasa haus pada responden sebelum diberikan permen karet pada pasien GGK yang menjalani hemodialisa di RSU Haji Provinsi Sumatera Utara Tahun 2020 merasakan kategori haus sedang $(50.0 \%)$.

2. Mayoritas rasa haus pada responden setelah diberikan permen karet pada pasien GGK yang menjalani hemodialisa di RSU Haji Provinsi Sumatera Utara Tahun 2020 merasakan kategori haus ringan $(65.0 \%)$. 
Ada pengaruh pemberian permen karet pada pasien GGK yang menjalani hemodialisa di RSU Haji Provinsi Sumatera Utara Tahun 2020 dengan Hasil analisis data menggunakan uji Wilcoxon diperoleh nilai Pvalue $=0,001(<0,05)$.

\section{Referensi}

Alfrida Ra'bung, Samuel. 2019. Pengaruh mouthwash disertai mengunyah permen karet xylitolterhadap ph saliva, laju aliran saliva dan xerostomia pada pasien yang menjalani hemodialisis, tesis, program studi magister keperawatan fakultas keperawatan universitas airlangga Surabaya.

Andra, S. W., dan Yessie, M. P. 2013. KMB 1 Keperawatan Medikal Bedah Keperawatan Dewasa Teori dan Contoh Askep. Yogyakarta: Nuha Medika.

Andreas, Gracela, G. T. 2019. Pengaruh Mengunyah Permen Karet Terhadap Rasa Haus Pada Pasien Hemodialisa. Jurnal Nutrix Fakultas Keperawatan Universitas Klabat. Volume 3, No.1.

Anis., Fuad, dan Nugroho, Kandung Sapto. 2015. Panduan Praktis Penelitian Kualitatif. Yogyakarta: Graha Ilmu.

Ardiyanti, A., Armiyati, Y., dan Arif SN, M. S. 2015. Pengaruh Kumur Dengan Obat Kumur Rasa Mint Terahadap Rasa Haus Padapenyakit Ginjal Kronis Yang Menjalani Hemodialisadi SMC RS Telogorejo. Jurnal Keperawatan Dan Kebidanan (JIKK).

Arfany, N. W., Armiyati, Y., dan Kusuma, M. A. B. 2014. Efektifitas mengunyah permen karet rendah gula dan mengulum es batu terhadap penurunan rasa haus pada pasien penyakit ginjal kronis yang menjalani hemodialisis di RSUD Tugurejo Semarang.Jurnal Keperawatan dan kebidanan (JIKK).

Ariani, N. P., Yasa , D. G., dan Arisusana, M. 2014. Pengaruh mengunyah permen karet xylitol terhadap rasa haus pada pasien CKD dengan terapi hemodialisa. Jurnal Keperawatan.

Aroem. 2011. Gambaran kecemasan dan kualitas hidup pada pasien yang menjalani hemodialisa. Jurnal Fakultas Kedokteran Universitas Sumatera Utara.

Asmira. Dewi,, Nurchayati, S., dan Jumaini, J. 2018. Perbedaan efektifitas mengunyah permen karet rendah gula dan mengulum grapeice cube terhadap rasa haus pada pasien gagal ginjal kronis yang menjalani hemodialisis. Jurnal Online Mahasiswa (JOM) Bidang Ilmu Keperawatan, 5, 304-312.

Baughman, D. C., dan Hackley, J. C. 2012. Keperawatan Medikal-Bedah Buku Saku Dari Brunner \& Suddarth (Terjemahan). Jakarta: EGC.

Bilotta, Kimberly. 2012. Kapita Selekta Penyakit dengan Implikasi Keperawatan. Jakarta: EGC.

Black, J. M., dan Hawks, J. H. 2014. Keperawatan Medikal Bedah: Manajenen Klinis Untuk Hasil Yang Diharapkan. Edisi 8. Jakarta: Salemba Medika.

Cahaya, Intan, Supratti, dan Santoso, Budi. 2017. Effect permen karet rendah gula terhadap penurunan keluhan xerostomia dan laju aliran saliva pada pasien PGK yang menjalani hemodialisa. Jurnal majalah kedokteran sriwijaya, th49.

Depkes RI. 2013. Hasil Riskesdas 2013 Departeman Kesehatan RepublikIndonesia. Diakses dari: http://www. depkes. go. id/ resource/ dowload/ general/ hasil \% 20 riskesdas \% 2013. pdf.

Diyah C Sufiana P dan Syaifudin. 2015. Hubungan Lamanya Hemodialisis dengan Kualitas hidup pasien gagal ginjal di RS PKU Muhammadiyah Yogyakarta. Jurnal keperawatan. 
Fan, W., \& Zhang, Q. 2013. Study on the clinical significance and related factors of thirst and xerostomia in maintenance hemodialysis patients. Kidney and Blood Pressure Research, 37: 464474.doi:10.1159/000355717.

Fatmah. 2010. Gizi lanjut usia. Jakarta: Erlangga

Febriyantara A. 2016. Hubungan antara kepatuhan menjalani terapi hemodialisa dan kualitas hidup pasienchronic kidney disease (CDK) di Rumah Sakit Dr. Moewardi. skripsi. Solo: Universitas Muhammadiyah Surakarta[diunduh 15Desember 2016]. Tersedia dari:http://eprints.ums.ac.id/

Furness, S., Bryan, G., Mcmillan, R., \& Hv, W. 2013. Interventions for the management of dry mouth : non- pharmacological interventions (Review). The Cochrane Database of Systematic reviews (8), 1-38. https://doi.org/10.1002/14651858. CD009603. pub3. www. cochranelibrary. Com

Guyton, Hall JE dan Hall. 2016. Textbook of Medical Physiology. 13th ed. Philadelphia (PA): Elsevier, Inc.

Hall J.E. Guyton A.C. 2012. Buku ajar fisiologi kedokteran. Edisi 11. Jakarta: EGC.

Ignatavicius, D. D., dan Workman, m. L. 2010. Medical Surgical Nursing: Clients Centered Collaborative Care. Sixth Edition, 1 \& 2 . Missouri: Saunders Elsevier.

Kowalak. 2011. Buku Ajar Patofisiologi. Jakarta: EGC.

Kozier, Erb, Berman, dan Snyder. 2011. Buku Ajar Fundamental Keperawatan : Konsep, Proses \& Praktik (7 ed., Vol. I). Jakarta: EGC.

Mohammad Fajar Sodik \& Abdul thalib. 2018. Pengaruh pemberian permen karet terhadap lama waktu menahan rasa haus pasien yang menjalani hemodialisa di RSUD Dr. M. Haulussy Ambon, Pasapua Health Journal, 1(1), 27-34.

O'callaghan, C. (2010). At a glance sistem ginjal (2nd edition ed.). (E. Yasmine, penerj.) Jakarta: Erlangga.

Perhimpunan Nefrologi Indonesia (PERNEFRI). (2016). Konsensus Hemodialisis. Jakarta Potter, perry. 2010. Fundamental of nursing: consep, proses and practice.edisi 7. Vol. 3. Jakarta: EGC.

Price, S.A., dan Wilson, L.M. 2013. Patofisiologi Konsep Klinis Proses - Proses Penyakit. Edisi VI. Jakarta: EGC.

Ratnawati. 2014. Efektifitas Dialiser Proses Ulang (DPU) Pada Penderita GGK (Hemodialisa). Jurnal Ilmiah widya. Volume 2 Nomor 1. Diakses tanggal 24 November 2014.

Rietveld, C. A., Medland, S. E., Derringer, J., Yang, J., Esko, T., Martin, N. W., Agrawal, A. 2013. GWAS of 126,559 individuals identifies genetic variants associated with educational attainment. Science, 1235488

Rodian, M., Satari, M. H., \& Rolleta, E. 2011. Efek Mengunyah Permen Karet Yang Mengandung Sukrosa, Xylitol, Probiotik Terhadap Volume, Kecepatan Aliran, Viskositas, pH, Dan Jumlah Koloni Streptococcus Mutans Saliva. Abstrak.

Said H, dan Mohammed H. 2013. Effect of Chewing Gum on Xerostomia, Thirst and Interdialytic Weight Gain in Patients on Hemodialysis. Jurnal nutrix keperawatan.

Sari, N. N. G. 2016. Permen Karet Xylitol Yang Dikunyah Selama 5 Menit Meningkatkan Dan Mempertahankan pH Saliva Perokok Selama 3 Jam. Tesis, Universitas Udayana.hal. 20-23.

Sherwood, L. 2012. Fisiologi Manusia dari Sel ke Sistem. Edisi 6. Jakarta: EGC. h. 708710.

Smeltzer, S.C., Bare, B.G., Hinkle, J.L., Cheever, K.H. 2010. Brunner and Suddarth's text book of medical surgical nursing. (11th ed.). Lippincolt. 
JINTAN: Jurnal Ilmu Keperawatan

ISSN 2774-468X (Media Online)

Vol 1, No 1, Januari 2021

Hal 36 - 47

Suwitra, K. 2016. Penyakit Ginjal Kronik. Dalam: Sudoyo, A.W., Setiyohadi, B., Alwi, I., Marcellus, S.K., Setiati, S., Edisi 4. Buku Ajar Ilmu Penyakit Dalam Jilid 1. Jakarta: Pusat Penerbitan Departemen Ilmu Penyakit Dalam FKUI, 570-573.

United states renal disease system (usrds). 2013. Usrdsannual data report (dalam kusuma, 2013). 